\title{
Constructing the Atlantic's Boundaries: Forced and Coerced Labor on Imperial Fortifications in Colonial Florida
}

\author{
James Coltrain
}

One might not expect that the most pressing duty for a Spanish colonial governor would be to stack bricks. But in 1683 Florida Governor Juan Márquez Cabrera was consumed with just that task, trying to fill a remaining gap in St. Augustine's new stone fort. Working alongside him were not only soldiers, clergy, and townspeople, but also Native American peons, African slaves, Spanish convicts, and even former English prisoners. We could read the official account of the governor's contribution as political theater, but another observer on site remembered how Márquez worked so urgently and cursed so fiercely, that only calm words of a town priest prevented a mutiny. The governor and his diverse crew were working to shore up the Castillo San Marcos, a massive stone fort, the construction of which the Spanish authorities had authorized following a devastating pirate attack in 1668. The governor was so on edge because a new band of pirates was waiting downriver, and would again sack the town in days if the fort were indefensible. In seventeenth-century St. Augustine, finding a quality workforce could be the difference between life and death. ${ }^{1}$

1 The chief archival sources for this paper come from the records of the Archivo General de Indias in Seville, Spain. A large number of the documents from those holdings are reproduced in the Stetson Collection, an exhaustive microfilm series with copies of correspondence relating to the colonial history of Spanish Florida. The copy of the Stetson Collection I consulted is kept at the University of Florida. In many cases I have used transcriptions and translations of Stetson records prepared by Luis Arana while researching the Historical Structure Report on the Castillo for the National Parks Service. His papers are held in the Parks Service Archives in Jacksonville Florida. Stetson Collection "58-1-21/44 1693" Smathers Library, University of Florida, Gainesville, FL (Hereafter Sc), "Luis Arana Papers, Stetson Transcripts 1668” Parks Service Archives, Jacksonville, FL (Hereafter JPs); Luis Arana Defenses and Defenders at St. Augustine (St. Augustine: St. Augustine Historical Society, 1999), 68, Albert Manucy, The History of Castillo de San Marcos and Fort Matanzas from Contemporary Narratives and Letters (Washington: National Park Service, 1943), 17; Albert Manucy and Luis Arana The Building of the Castillo de San Marcos (St. Augustine: Eastern National Park \& Monument Association, 1977). 
In many ways that night's scene resembles the picture some historians have given of life in the Atlantic World. A wild place, where different races, cultures, and languages collided, adapting to new problems, exploring new opportunities, and creating identities far away from the view of European powers. ${ }^{2}$ Though remotely located, desperately vulnerable, and chronically underfunded, St. Augustine was in need of a fort that would take hundreds of workers decades to build. Such a scenario seems like just the recipe for a transcendent Atlantic experience, where unfree workers might capitalize on the dire need for labor, assert their autonomy from a weak imperial authority, and improve their social standing.

Over nearly a century of work constructing and maintaining the Castillo many of St. Augustine's forced workers seemed to do just that. Slaves, peons, and prisoners seized upon opportunities from pragmatic Floridian authorities, distinguishing themselves professionally, increasing their social and material standing, and sometimes even gaining their freedom. But such advancements were not the result of wily Atlantic creoles flaunting imperial legitimacy. Because of the constant threat of violence from competing powers in Carolina, Georgia, and elsewhere in the Caribbean, the same vulnerabilities that could have chipped away at Spanish control made the entire surrounding population dependent on the empire for protection inside the rising Castillo. The construction process did push the local government, and even the empire itself, to offer greater recognition in the community to all levels of St. Augustine's diverse workforce. But these workers' challenges to the Spanish social conventions only succeeded to the degree that they accommodated, rather than subverted, the wider goal of sustaining the empire. In a hotly contested Atlantic World, imperial presence remained a key factor in the experience of unfree laborers.

2 A number of historians have stressed the transnational qualities of the Atlantic World, often emphasizing fluid identities, and negotiated or even subverted imperial authority. Nicholas Canny and Anthony Pagden, eds., Colonial Identity in the Atlantic World, 1500-180o (Princeton: Princeton University Press, 1989); Peter Linebaugh and Marcus Rediker, The Many-Headed Hydra: Sailors, Slaves, Commoners, and the Hidden History of the Revolutionary Atlantic (Boston: Beacon Press, 2001); Christine Daniels and Michael V. Kennedy, eds., Negotiated Empires: Centers and Peripheries in the New World, 1500-1820, 1st ed. (London: Routledge, 2002); David Armitage and Michael J. Braddick, eds., The British Atlantic World 1500-1800 (London and New York: Palgrave Macmillan, 2002); Elizabeth Mancke and Carole Shammas, The Creation of the British Atlantic World (Baltimore: The Johns Hopkins University Press, 2005); Marcus Rediker, Villains of All Nations: Atlantic Pirates in the Golden Age (Boston: Beacon Press, 2005); Jeremy Adelman, Sovereignty and Revolution in the Iberian Atlantic (Princeton: Princeton University Press, 2009); James H. Sweet, Domingos Alvares, African Healing, and the Intellectual History of the Atlantic World, 1st ed. (Chapel Hill: University of North Carolina Press, 2011). 
A small outpost like St. Augustine could hardly have faced a greater labor challenge than the construction of a permanent stone fort. The small coastal town had served for decades as the last stop for Spanish ships heading from the Caribbean back to Europe, and had neither enough quality land nor mineral wealth to ensure economic independence or even self-sufficiency. Augustinians instead depended heavily on the situado, a yearly bulk subsidy payment dispensed by the Viceroy of New Spain that often arrived years overdue. Even basic correspondence could take weeks or months, and many major decisions required approval from the crown, so erecting new defenses in such an isolated location presented a formidable task. Fortifications were the largest and most expensive public works in all of North America well into the eighteenth century, and Florida's Castillo would prove no exception. To complete a stone fortification within a decade was very quick work, and most constructions stretched on for years more. The enterprise required a well balanced staff of trained craftsmen and unskilled workers, all of whom would need to adapt quickly to a location's specific engineering challenges. Spain's inconsistent support of St. Augustine made makeshift local solutions even more likely. As a remote military outpost incapable even of growing enough food to subsist, St. Augustine already depended on royal funding for the entire construction. But authorized funds were often slow to make it through New Spain's sprawling bureaucracy, leaving Florida's governors to come up with creative solutions to the fort's labor needs. Florida's geographical distance also made Spanish oversight infrequent, allowing local leadership even more space to work outside of imperial norms. ${ }^{3}$

The final design of St. Augustine's new fort ensured its construction would dominate local affairs for many years. A fortunate deposit of local stone meant that the new Castillo San Marcos could be a formidable, modern structure. The fort's design was simple by European standards, but hulking and massive on the North American coast. It was a basic square shape, with four diamond shaped bastions extending from each corner. After finally securing the initial funds and the first work crews, construction began in 1672 . Workers built each of the imposing bastions separately, but the fort was not completed until more than twenty years later in 1695. Even after finishing the fort, work crews continued with repairs, renovations, and additions for six decades more, leaving a dramatic mark on the St. Augustine community well into the eighteenth century.

Florida's early attempts at meeting its labor needs involved the use of local natives, just as Spain's imperial authorities preferred. Filling even the initial

3 Amy Turner Bushnell, Situado and Sabana:Spain's Support System for the Presidio and Mission Provinces of Florida (New York: American Museum of Natural History, 1994); SC 2-4-1/19; Queen Regent, SC 2-4-1/19/1; Arana, Defenders, 3-4; Cendoya to King, SC 58-1-26. 
150 positions in a town of only hundreds required the governor Manuel de Cendoya to reach out to the frontier and employ native peons. These Indian workers were paid a small cash wage along with maize, but Spanish soldiers had to force their service to varying degrees. Overseers kept many of the natives past the end of their designated terms, preventing them from tending to their own families and crops in the local provinces of the Guale, Timucua, and Apalache language groups. This compulsory, hard service placed a strain on relations with surrounding tribes, leading local clergy to protest the practice. Frontier priests complained that because the peons were already responsible for their own agricultural sustenance, as well as work that the crown required in the fields of wealthier townspeople, the extra fort service, paid or not, constituted an unnecessary additional strain. ${ }^{4}$

A fearsome epidemic strained St. Augustine's precarious labor solution within the first year of construction. The official correspondence called the disease, possibly smallpox, "contagion" and as it ravaged the inland of Florida it also took its toll on the St. Augustine community. The extreme working conditions worsened the situation for the primarily native workforce. Toiling long hours in harsh conditions made the group particularly vulnerable, attempting new tasks and straining new muscles, breathing in the dust from sawed timbers and cut stone. Governor Cendoya was less sympathetic, thinking the natives naturally unfit for the hard labor. His frustrations may have stemmed from the hard tasks that now fell to him, as he and his soldiers began working at the site themselves, unable to find replacements for their Indian staff. Cendoya had to pay the enlisted men's extra wages out of his own salary, and the soldiers' service amplified the possibility of friction among those Castillo workers who had survived the plague. ${ }^{5}$

The susceptibility of indigenous workers to disease led to St. Augustine's first staffing adaptation, as Governor Cendoya quickly petitioned for thirty African slaves from Havana to bolster the crew. Imperial officials had previously frowned on the use of black labor, but as the situation grew more serious, they gave in to the governor's request. Subsequent governors made similar moves, but as early as 1687 African slaves escaping from English Carolina also began finding their way into Florida. Florida's governor Diego de Quiroga y Losada refused to return or pay the English for the first escapees, and eventually freed the group under the condition that they adopt Catholicism and work on the Castillo. ${ }^{6}$ As the

4 Cendoya, sc 58-2-3/5; Arana, Defenders, 30-31.

5 Cendoya, SC 54-5-11/10.

6 Governor Quiroga's decision to free Catholic converts received confirmation from the crown in 1693 . Some later refugees' bids for freedom were complicated by periods of truce 
decades passed such incidents became more common. Yamasee Indians led another group into Florida a few years later, after rumors had made their way far enough to the north that black slaves began to cite the previous imperial amnesties as they arrived, offering loyalty and conversion to Catholicism in exchange for freedom. Florida's governors in the early eighteenth century continued to put the ex-bondsmen to work on the fort while the Spanish Council of the Indies deadlocked in debate over the diplomatic consequences of endorsing the retention of English escapees. Gradually it became clear that if English slaves would embrace the empire and its church, they would find a freer life upon escaping to the Castillo, regardless of the crown's official policy. St. Augustine's officials kept some of the escaped slaves in an ambiguous serf-like state, guaranteeing them amnesty and a role in the community, but requiring they remain to labor on the fort. Nevertheless even their hard working conditions at the Castillo would have been more tolerable than grueling work on sugar islands or rice plantations, and black slaves from English colonies continually braved great dangers to take up carpentry, masonry, and earth moving at the Castillo. ${ }^{7}$

By the heyday of the Castillo's construction in 167os and 168os, St Augustine's labor demand had produced a wildly eclectic and multicultural group of workers. There were still Indian peons working on coerced schedules to bring small wages to their inland families. Joining them were black workers of various origins and predicaments including slaves imported from Spanish Cuba, escapees from British Carolina or Georgia working in a serf-like state, and other fully free black laborers. Ethnically Spanish workers had a similarly wide assortment, from Iberian convicts, to locally-born mestizos, to regular soldiers from throughout the empire who might be assigned construction duties. Perhaps the most unlikely laborers were English colonists from Charleston, who had been taken prisoner in 1670 after their ship ran aground in northern Florida, and kept following a botched diplomatic mission to reclaim them. Two of the group, William Carr and John Rivers, before had been practicing masons and worked at the fort as a stonecutter and lime burner. Thus, a varied group from a spectrum of ethnicities and nearly a half dozen languages began a decadeslong project that would help preserve the imperial power that forcibly compelled many of their labors. ${ }^{8}$

with Britain. In 1733 the crown again declared freedom for converted escapees, but did not grandfather in all who had arrived during the interim. Manucy, Building, 34; SC " $58-1-24 / 25$," “54-4-13/126."

7 John Jay Tepaske, The Governorship of Spanish Florida (Durham: Duke University Press, 1964), 4 .

8 JPS, Historic Structure Report, 8. 
The diverse group provided plenty of potential grounds for internal strife that could undermine both the project and Spanish authority. The indigenous laborers might speak any of three major local languages as their native tongue, and had longstanding grievances with each other and the empire. Amongst the Spanish there were significant class divisions revolving around birthplace and ethnic origin, as well as town disputes that frequently split residents between the opinions of religious and civil authorities. Religion also provided a potential point of contention for workers from Protestant English colonies, whom St. Augustine's officials expected to become loyal Catholics. But the most important source of potential stress was the monotonous and often grueling labor required for building, made more difficult by frequent setbacks and local disasters.

The project of building the new fort was already the most extensive enterprise ever conducted in St. Augustine before the first stone was laid. Augustinians had not even the basic tools to begin construction, so the first workers traipsed into to the woods to gather timber for axes, mallets, hammers, and picks. Workers also built larger timber machinery, scaffolding, barrels, storage huts, small cranes, carts, rafts, and docking points. Because of St. Augustine's isolation and the stringent budget, officials could not even count on receiving manufactured metal goods for the undertaking. Instead Spain sent large bars of iron and lead, which teams of smiths had to beat and cast into axe heads, crowbars, pulley wheels, and nails. ${ }^{9}$ As soon as 1672 , there were 150 laborers working daily in teams of $5^{0}$, some gathering oyster shells to burn in the lime kilns, others mixing lime into mortar, and still others quarrying and carrying stone from downriver. Extracting the local coquina stone that would form the fort walls became a specialized skill over the many years of construction. Coquina is an extremely coarse limestone found in coastal areas. Named from the Spanish word for cockle shell because many bivalve pieces are still recognizable in its stone sections, the material is a soft, often brittle compaction of marine detritus. ${ }^{10}$

The fickle nature of coquina stone meant local authorities were likely to respect anyone with a talent for extracting it, regardless of social rank. The stone varied greatly in its quality, and a keen grading skill was needed to separate masonry worthy blocks from brittle castoffs. Small teams hacked long grooves into the stone surface to outline large blocks, before using long pry bars to break the future bricks loose. It was grueling work, with the hot sun reflecting off the bright white quarry walls. Laborers walked across a bed of

$9 \quad$ JPS, Miscellaneous, $82-84$.

10 Tepaske, 4, 78; JPS Historic Structure Report, 12. 
crumbled seashell shards, which other workers sometimes collected to use for paving in tabby, a coarse, low grade plaster. Even before digging could begin, the quarries had to be cleared of tangled trees and brush, and once workers had lifted out the heaviest wet blocks and hit water, the entire process would begin anew. Laborers would load the cut stones onto ox carts and then gingerly on to rafts to float up the river to the old fort. The workers piled the blocks near the shore to bake like adobe, shedding water content and hardening into usable bricks. The process could take months or even years, and so the quarrymen's work quickly accumulated in neatly stacked piles waiting to be laid. ${ }^{11}$

Once enough stones had been quarried, the proper construction of the fort began. Masons carefully laid strong foundation courses that would support the thick and heavy bastion walls, and then delicately lifted the heavy stone blocks onto the rising walls using cranes carpenters had constructed on site. To bolster the diamond bastions against cannon shot, workers conducted significant earthmoving operations using only buckets, filling each bastion to the brim with dirt. Unlike the precision needed for stone grading, carpentry and lime burning, this was menial work, often frustrated by rains that would make a muddy slurry of the manmade earthen banks. Once the earth filled walls were completed, laborers would seal them with coarse white plaster to prevent much moisture from seeping through the porous coquina stone. The plaster coating would require frequent maintenance, and keep similar laborers busy for decades to come.

Challenges from Florida's elements forced Florida's governors and engineers to stay pragmatic and efficient in their approach towards labor. In 1674 the Atlantic produced a powerful hurricane that made a sloppy mess of the Castillo's neat beginnings. The quickly built shacks sheltering the smithys and lime barrels would have been hard hit, leaving unattended tools mired in mud. Spilt lime and charcoal could have made for a chemical mess, while piles of cut stone would likely have sunk into the soft soil, leaving laborers to carefully clean the bricks so they would bond tightly to mixed mortar. Unfinished earthen embankments slid down, swallowing up tools, buckets, and even a cannon that workers later had to fish out. Beyond regular tropical storms that caused such problems including another major hurricane in 1707, Florida's normal climate could provide plenty of its own misery, from sweltering, sticky summers to winters cold enough to freeze the water in local swamps. ${ }^{12}$

Even more dangerous to the continued work on the Castillo was the unrelenting threat of violence from imperial rivals. French and English pirates

\footnotetext{
11 Arana, Defenders, 31.

12 Ponce, SC 58-1-26/24.
} 
continued to raid various Florida settlements well into the eighteenth century, with specific attacks in 1683, when Governor Márquez was noisily imploring his men to finish the fort, and again in 1686 when the infamous pirate Nicholas Grammont threatened the town before being driven away in a skirmish. ${ }^{13}$ As the British colonies of Carolina and Georgia expanded, violent raids by the English and their allied tribes punished Spanish Indians' settlements surrounding St. Augustine nearly every year. In 1702, a Carolinian expedition besieged the whole of St. Augustine, and though the local labor force survived largely unharmed inside the fort they had constructed, the workers watched English soldiers burn the entire town, leaving only smoldering ruins to the hungry survivors. Sporadic skirmishes and rumors of such attacks only intensified as the eighteenth century progressed, culminating in another harrowing siege in 1740 by Georgian militia and British regulars that again nearly pushed the town to starvation.

Long periods of neglect from the wider empire could also sap the motivation of the workers responsible for the Castillo. Many negative aspects of the castle environment itself contributed to an ambivalence that could undercut any sense of accomplishment or recognition workers might have gained. When St. Augustine's military companies began conducting their regular business inside the new fort in the $168 \mathrm{os}$, it became the center of all town activity, and laborers became of secondary importance, expected to stay clear of the structure's primary occupants. As St. Augustine continued to suffer periods of neglect from the Spanish authorities, current and former builders could feel the frustration of seeing their hard work decay and crumble without the financial support to maintain proper repairs. During the early years of the eighteenth century, some of the fort's interior rooms were so dilapidated they were unsafe to enter, and the workers and soldiers on site reported a host of sicknesses and infirmities. Coupled with the ever present threat of violence from English invaders, the condition of the fort could produce palpable feelings of anxiety, frustration, and resentment amongst all levels of laborers. For some near the bottom, these resentments were much more tangible. When St. Augustine's officials began locking away some convicts and slave workers within the fort's finished rooms to prevent wandering at night, those laborers found themselves prisoners of the structure they had helped to build. ${ }^{14}$

\footnotetext{
13 Manucy, Building, 30,54-56; Manucy,Letters, 17, 20; Arana, Defenders, 68;JPs, Miscellaneous, 82-84.

14 Tepaske, 4,78; JPS Historic Structure Report, 12; JPS “Chronology" 12; SC 58-1-23/358; 58-1 -27/a-46; JPS “Chronology” 13; SC 58-1-28/87; 58-1-28/93.
} 
To prevent St. Augustine's workforce from splintering into revolt amidst so many stresses, local Spanish officials continually compromised imperial expectations to expand the community opportunities available to workers. The pay scale of early construction laborers is emblematic of this process. Cendoya and early governors initially used the labor pay scale to inscribe empire-wide Spanish prejudices regarding race and ethnicity. In general Spanish laborers earned more than their Indian counterparts, who in turn collected more than those few of mixed or African ancestry. But pay scales from later years included opportunities for workers to rise somewhat above their racial status. Because of the high degree of skill needed to cut coquina blocks without them breaking, or to keep kiln fires hot enough for burning lime, some workers could supplant their social betters in professional positions. An Indian stonecutter could make double what an unskilled Spanish laborer could, even if his take was still well below that of a Spaniard in the same profession. This potential for advancement likely helped mute some of the potential friction that could result from unjust divisions amongst compelled manual laborers. But there was no racial class that governors regarded lower than those who had been subversive. Other than slaves, Spanish convicts were the only workers receiving no pay, only rations. ${ }^{15}$

Spanish officials in Florida also attempted to preserve order by offering black workers a far greater recognition as imperial subjects than was available in many rival English territories. While many British colonies were solidifying racial distinctions in law that would term all blacks chattel, black residents of St. Augustine, both slave and free, lived as persons and members of the community. First and foremost, officials expected black workers in Florida to become full members of the Catholic Church, signifying their worth under divine mandate. Ex-slaves from English colonies learned to speak Spanish and discarded their simple slave sobriquets for full Spanish names. Many married native women raised mixed children who would be of marginally higher status. Black slaves could participate in the justice system and testify in proceedings, though their lower racial status often earned them questionable results. Despite very real limitations, black slaves experienced far greater acknowledgement and possibilities in Florida than their counterparts in South Carolina or Georgia. Those who remained enslaved were very much unfree, but even as they toiled under the threat of the lash, the continual flight of refugees from the north proved that Spanish policy had created a significant difference for black slaves across imperial boundaries. ${ }^{16}$

15 Royal Officials, SC "54-5-20/30"; “54-5-14/142"; “2-4-1/19/5”; JPS, Historic Structure Report, 7.

16 Jane Landers, Black Society in Spanish Florida (Champaign: University of Illinois Press, 1999), 23-28, Fort Mose Gracia Real De Santa Teresa De Mose:A Free Black Town in Spanish Colonial 
When international violence did come again to Florida many of St. Augustine's unfree laborers preferred the prospect of participating in the Spanish community to the even greater dangers of siding with foreign invaders. In both the 1702 and 1740 sieges, governors recognized the brave service of many slaves in battle, some in defending the very fort they had helped construct. Members of native tribes who had worked under coercion on the Castillo exposed and foiled a plot during the 1702 siege when a local native allied with the English tried to persuade other refugees to revolt and sabotage the Spanish defense. Such acts were not necessarily reflective of an enthusiastic loyalty among all St. Augustine's enslaved and coerced workers, but they do suggest that even unfree laborers often operated within the Floridian community in roles similar to those of other lower class subjects.

These measured contributions of unfree laborers to Spanish rule are also evident in St. Augustine's longstanding record of relatively little labor strife. The colony did not suffer any significant worker-led stoppage, mutiny, or slave insurrection during the years of the Castillo's construction. Despite a host of stressful challenges, divisions among the workforce, and the value of information on the construction to rival English agents, few laborers rebelled against Spanish authority. Even as St. Augustine's leaders actively tried to instigate slave revolts in Carolina through rumors of freedom in Florida, a variety of forced and coerced laborers persisted at the Castillo without major incident. ${ }^{17}$

The success that St. Augustine's authorities achieved by giving unfree laborers a greater stake in the community eventually earned support from the Spanish crown. Having earlier prohibited governors from reimbursing the British masters of slaves escaping to St. Augustine, royal officials decided by 1733 to make good on the rumors and the fuzzy precedent that had led hopeful black slaves to flee into Florida. With the continued growth of British settlements and the founding of Georgia, creating slave unrest in the colonies to the north had become even more appealing. The crown ruled that from that point forward no slaves escaping from English colonies would be turned away, and that all incoming slaves who accepted Catholicism would be granted new freedom as Spanish subjects. The need for adequate labor had not only changed the prospects for St. Augustine's black workers, but had altered the institution

Florida (St. Augustine: St. Augustine Historical Society, 1992); Sue Peabody and Keila Grinberg, Slavery, Freedom, and the Law in the Atlantic World: A Brief History with Documents (New York: Bedford/St. Martin's, 2007).

17 JPS, Chronology, 12; Zuniga, SC 12789-12786; 12859-12854; Charles W. Arnade, The Siege of St. Augustine In 1702 (Gainesville: University Press of Florida, 1959), 45, 54, 15-16; Bushnell, 98 . 
of slavery in Florida. ${ }^{18}$ By the middle of the eighteenth century such decisions had led to former slaves inhabiting positions uncommon elsewhere in the Spanish empire and nearly unheard of in the colonies of imperial rivals. St. Augustine had so many productive black subjects that in 1738 Governor Manuel de Montiano helped establish Fort Mose, a settlement of mostly escaped slaves, many of whom had worked on the Castillo. Mose had a full company of deployed black militiamen, and these soldiers held the same rank and status as their ethnically Spanish counterparts in St. Augustine. ${ }^{19}$

Yet no matter how fully many workers took advantage of opportunities afforded by Spanish rule, no serious threat to unfree labor or the Spanish authority that endorsed it ever materialized. When Augustinians evacuated Florida following a treaty with Britain after the Seven Years' War, hundreds of slaves appeared on the registers. The Castillo still featured an overseer's quarters, and the fort still likely held some workers locked inside when the drawbridge was raised each night. Despite the distinction and respect that skilled workers in lower racial categories had earned over simple laborers of Spanish descent, labor on the Castillo remained a common punishment for St. Augustine's undesirables. Although they took advantage of the opportunities offered in the Castillo's construction, St. Augustine's lower class laborers never gained the greater autonomy that might have come from challenging imperial authority. ${ }^{20}$

Such challenges remained unlikely because the persistent threats of foreign violence towards St. Augustine never abated. English raiding threatened the property, freedom, religious practice, and lives of all Spanish Floridians, and unfree laborers were in special danger of being captured and sold into the brutal sugar slavery of the English Caribbean. All of St. Augustine's residents, including those from the lowest classes, remained dependent on the cash, troops, and armaments of the Spanish empire to keep the Castillo defensible, and ensure protection from the rival English. Thus, even as the local Spanish leaders eased imperial expectations for the social order, and unfree laborers used their value and skills to help carve out new opportunities, the gains made by workers all ultimately reinforced the security of Spanish rule.

Even the social adaptations that local officials made to meet their labor needs still reinforced the broader culture of imperial Spain. Opportunities for professional distinction and social mobility held such value because Florida still maintained a complex racial hierarchy. The incorporation of all unfree

\footnotetext{
18 SC 58-1-24/258.

19 Bushnell, 204; Arana, Defenders, 70; Tepakse, 8; Landers, Black Society, 29-37.

20 sc 86-7-22/7; Manucy, Building, 46.
} 
workers into the community as subjects depended heavily on the use of the Spanish language and the adoption of a state-supervised corporate Catholicism, both of which bound laborers even closer to the empire. All of these measures were so noteworthy because they contrasted with the policies of Britain's nearby rival colonies. In other contested areas of North America the distinct imperial cultures of Britain and France would produce much different solutions to the problem of finding the labor for fort construction. ${ }^{21}$ Even in an Atlantic world full of creative adaptations, unexpected encounters, and relatively light supervision, the influence and culture of empires were key factors in defining the experience of forced and coerced labor. Just as in other aspects of early American life, the careers of fort laborers sometimes presented diverse possibilities, but were ultimately constrained by imperial rule. Workers from four continents had transcended the Atlantic to build in St. Augustine, but the product of their labor had only made North America's imperial boundaries all the more evident.

21 For instance, the construction of the French Fortress Louisbourg relied mostly on the paid labor of stationed soldiers working during their leave, and a few private contractors, Bruce W. Fry, "An Appearance of Strength" the Fortifications of Louisbourg, 2 vols. (Ontario: Parks Canada, 1984); A.J.B. Johnston, Control and Order in French Colonial Louisbourg, 1713-1758 (Lansing: Michigan State University Press, 2001). Many British frontier forts like Fort Stanwix were built using primarily on duty soldiers, with little private or coerced labor; John F. Luzader, The Construction and Military History of Fort Stanwix (Washington, D. C.: Office of Park Historic Preservation, National Park Service, 1969); Lee H. Hanson and Dick Ping Hsu, Casemates and Cannonballs: Archeological Investigations at Fort Stanwix Rome, New York (Washington, D. C.: U.s. Department of the Interior, National Park Service, 1975). 